\title{
Annual Report on External Quality Assessment of Biochemical Genetics in Korea (2013)
}

Soo-Youn Lee, as Biochemical Genetics Subcommittee, The Korean Association of Quality Assurance for Clinical Laboratory Department of Laboratory Medicine \& Genetics, Samsung Medical Center, Sungkyunkwan University School of Medicine, Seoul, Korea

Corresponding author: Soo-Youn Lee Department of Laboratory Medicine \& Genetics, Samsung Medical Center, Sungkyunkwan University School of Medicine, 81 Irwon-ro, Gangnam-gu, Seoul 135-710, Korea

Tel: +82-2-3410-1834

Fax: +82-2-3410-2719

Email: suddenbz@skku.edu
Two trials of external quality assessment (EQA) of conventional newborn screening tests for phenylketonuria, galactosaemia, congenital adrenal hyperplasia, maple syrup urine disease, homocystinuria, and congenital hypothyroidism, as well as of newborn screening tests using tandem mass spectrometry were performed in 2013. A total of 32 specimens in the form of dried blood spots were distributed to 16 laboratories and the response rate of these laboratories was $100 \%$. Total T4, free T4, 17-hydroxyprogesterone, leucine, isoleucine, galactose, methionine, alanine, $\mathrm{C} 8 / \mathrm{C} 2, \mathrm{C} 8 / \mathrm{C} 10$, and $\mathrm{C} 5-\mathrm{OH}$ did not meet the accepted performance criteria. The mean, standard deviation, coefficient of variation, median, and cut-offs were evaluated for each analyte in the newborn screening tests. Two trials of EQA for the analyses of methylmalonic acid, vanillylmandelic acid, very long fatty acids, organic acids, and amino acids were also performed. A well-designed EQA program and continuous education would improve the performance of biochemical genetic tests.

(J Lab Med Qual Assur 2014;36:64-70)

Key Words : External quality assessment, Newborn screening, Tandem mass spectrometry, Molecular biology

\section{서론}

대한임상검사정도관리협회 생화학유전학분과에서는 1997 년도부터 선천성대사질환 선별검사에 대한 신빙도조사사업 을 시작하여 매년 2회의 신빙도조사를 시행해오고 있다. 탠덤 질량분석기(tandem mass spectrometry, MS/MS)를 이용한 광범위 선별검사에 대한 신빙도조사사업은 2004년도에 예비 신빙도조사를 실시한 이래 2007년도부터 정규항목으로 포함 하여 시행 중이다[1]. 2011년도부터는 예비 신빙도조사를 거 쳐 소변 메틸말론산(methylmalonic acid, MMA)와 바닐만델 산(vanillylmandelic acid, VMA), 소변 유기산 분석을 추가하 였고, 2012년도부터는 혈장 아미노산 및 초장사슬지방산(very long chain fatty acid, VLCFA) 종목을 추가하는 등 점차 사
업대상종목을 확대해오고 있다[2,3]. 저자들은 2013년 실시된 생화학유전학분과 신빙도조사결과를 분석하여 보고하고자 한 다.

\section{재료 및 방법}

\section{1. 대상 및 검체}

2013년도 2회의 생화학유전학분과 선천성대사이상검사 신 빙도조사대상항목 및 정도관리 검체 현황은 Table 1에 정리하 였다. 정도관리 검체는 상품화된 정도관리물질과 자가제조 검 체를 혼용하였고, 항목별 정상과 비정상 수치가 모두 포함되도 록 하였으며, 일부 검체에 대해서는 특정 대사질환에 특이적인 성분 다수를 동시에 포함시켰다. 
Journal of LABORATORY MEDICINE and QUALITY ASSURANCE

Soo-Youn Lee et al $\bullet$ Quality Assessment of Biochemical Genetics

Table 1. Test items and specimens included in the proficiency tests in 2013

\begin{tabular}{|c|c|c|c|}
\hline Test items & Category & Specimen & Number \\
\hline \multicolumn{4}{|l|}{ Neonatal screening } \\
\hline \multirow[t]{6}{*}{ Conventional } & Phenylketonuria & Dried blood spot & 20 \\
\hline & Congenital hypothyroidism (thyroid stimulating hormone, T4-total or free) & & \\
\hline & Galactosemia & & \\
\hline & Congenital adrenal hyperplasia (17-hydroxyprogesterone) & & \\
\hline & Maple syrup urine disease & & \\
\hline & Homocystinuria & & \\
\hline Expanded (by MS/MS) & About 40 inherited metabolic disorders (13 amino acids, 18 acylcarnitines) & Dried blood spot & 12 \\
\hline \multicolumn{4}{|l|}{ Other items } \\
\hline Vanillylmandelic acid & & Urine & 6 \\
\hline Methylmalonic acid & & Urine & 6 \\
\hline Organic acids & About 70 organic acids & Urine & 6 \\
\hline Amino acids & About 40 amino acids & Plasma & 4 \\
\hline Very long chain fatty acids & C22:0, C24:0, C26:0, C24:0/C22:0, C26:0/C22:0 & Plasma & 4 \\
\hline
\end{tabular}

Abbreviation: MS/MS, tandem mass spectrometry.

기본 선별검사의 대상질환으로는 페닐케톤뇨증(phenylketonuria, PKU), 갈락토스혈증(galactosemia), 선천성 부신과형성증(congenital adrenal hyperplasia), 단풍당뇨 증(maple syrup urine disease, MSUD), 호모시스틴뇨증 (homocystinuria, HCY), 선천성갑상선기능저하증 (congenital hypothyroidism) 등 6가지가 포함되었으며, 총 16기 관을 대상으로 총 32개(NST13-1-01-10, TMS13-1-01-06, NST13-2-01-10, TMS13-2-01-06)의 건조혈액여과지(dried blood spot, DBS) 검체를 발송하였다. MS/MS를 이용한 광 범위 선별검사항목으로 아실카르니틴(acylcarnitine, AC)은 1 차와 2 차에 각각 14 종목이 포함되었고, 아미노산은 11 종목이 포함되었다. DBS 정도관리 검체는 대부분 자가제조하여 준비 하였고, 질환양성 검체를 구하기 어려운 경우 상품화된 정도관 리물질(Bio-Rad Laboratories, Hercules, CA, USA)을 일부 사용하였다. DBS 자가제조를 위해 HIV항체와 B형간염 항원 이 음성인 혼합혈청에 식염수로 세척한 $\mathrm{O}$ 형 적혈구 적당량을 첨가하여 헤마토크릿을 약 $55 \%$ 가 되도록 맞춘 전혈을 준비한 후 측정대상 성분을 첨가하였다. 이를 여과지에 $75 \mu \mathrm{L}$ 씩 분주 하여 $\mathrm{DBS}$ 를 만든 다음 실온의 암실에서 충분히 말린 후 보관 하였다.

아미노산, 유기산, 초장사슬지방산검사를 위한 정도관리 검 체는 혼합 혈청(pooled serum) 또는 혼합 소변(pooled urine) 에 상품화된 표준물질(Sigma-Aldrich, St. Louis, MO, USA) 을 첨가하여 제조하였다. MMA와 VMA검사를 위한 소변 검체(MMA13-1-01-03, VMA13-1-01-03, MMA13-2-01-
03, MMA13-2-01-03)는 정상 성인의 혼합 소변에 MMA 표 준물질을 첨가하여 $\mathrm{MMA}$ 고농도인 검체를 제조하였고, 요 중 VMA 수치가 높은 환자들의 혼합 소변을 이용하여 VMA 정도관리 검체를 제조하였다. 유기산검사를 위한 소변 검체 (Organic acid13-1-01-03, Organic acid13-2-01-03)도 정 상 성인의 혼합 소변에 각 표준물질(Sigma-Aldrich, USA) 을 첨가하여 제조하였다. 1차에 succinylacetone, 4-hydroxyphenylpyruvate, 4-hydroxyphenylacetate, acetoacetic acid, adipic acid, 2-hydroxyadipic acid, 3-hydroxybutyric acid 표준물질을 첨가하였고, 2차에 glutaric acid, glutaconic acid, phenylpyruvic acid, 2-hydroxyphenylacetic acid, phenyllactic acid orotic acid, 2-keto-3-methylvaleric acid, 2-ketoisocaproic acid, 2-hydroxyisovaleric acid, lactic acid, adipic acid, 2-hydroxybutyric acid, 2-hydroxyisobutyric acid, 3-hydroxypropionic acid, phenyllactic acid, suberic acid, sebacic acid, pyruvate 표준물질을 첨가하였다. 혈장 아미노산 및 초장사슬지방산검사를 위한 혈장 검체(Amino acid13-1-01-02, Amino acid13-2-01-02, VLCFA13-1-01-02, VLCFA13-2-01-02)는 정상 성인의 혼합 혈장에 아미노산검 사의 경우 1차에 homocystein, methionine, phenylalanine 표준물질을 첨가하였고, 2차에 L-aspartic acid, L-glutamic acid, glycine, ornithine, methionine, phenylalanine, tyrosine 표준물질을 첨가한 혈장 검체를 제조하였다. 초장 사슬지방산검사의 경우 1 차 및 2차에 behenic acid (C22), lignoceric acid (C24), cerotic acid (C26) 표준물질을 첨가한 
혈장 검체 및 정상 검체를 발송하였다.

\section{2. 결과 판정 및 분석}

기본 선별검사의 경우에는 각 검사기관이 수행하고 있는 종 목에 대해 검사를 실시하여 결과수치와 함께 정상 및 비정상, 재검 여부 등을 판정하여 회신하도록 하였다. 결과분석 시 같 은 검사방법을 이용한 응답기관이 3 개 이상일 경우에 평균, 표 준편차, 변이계수를 구하였다. 또한 검사결과로부터 각 검사 기관에서 판독하는 정상 및 비정상, 재검 여부의 판정결과에 대해 분석하였다. $\mathrm{MS} / \mathrm{MS}$ 를 이용한 광범위 선별검사의 경우 $\mathrm{AC}$ 및 아미노산 결과수치와 함께 정상 및 비정상 판정, 기준 치(cut-off) 등을 회신하도록 하였다. 결과분석은 응답기관에 대해 판정결과 및 판정일치율과 각 기관에서 사용하고 있는 기 준치에 대한 평균, 중앙값, 최저값, 최고값에 대해 분석하였고, 각 기관의 검사성적에 대한 비교 평가 그래프를 제공하였다.

$\mathrm{MMA}$ 및 VMA 검사의 경우는 참여기관 수가 많지 않아 보 고된 수치들의 범위를 제공하는 것으로 결과 판정을 대신하였 으며, 측정값의 평균, 중앙값, 최저값, 최고값에 대해 분석한 표를 제공하였다. 유기산, 아미노산 및 초장사슬지방산검사 역 시 소수의 기관만 검사를 수행하므로 측정값을 비교할 수 있도 록 각 기관이 보고한 항목과 측정값을 제공하는 것으로 결과 판정을 대신하였다. 수탁기관에 대한 정도관리인증기준은 참 가기관 수 5 개 이상이면서, 결과판정일치율이 $70 \%$ 이상인 기 본선별검사종목을 대상으로, 종목별 보고결과의 정답 일치율 $80 \%$ 이상, 참가한 종목 전체 보고결과의 정답일치율 $90 \%$ 이 상인 경우로 하였다.

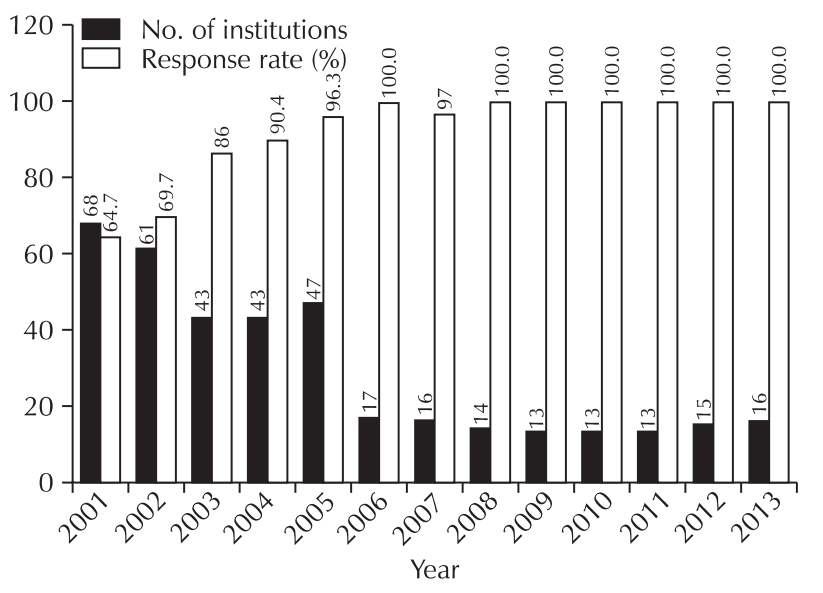

Fig. 1. The number of institutions that participated in the program, conducted by the Korean Association of Quality Assurance for newborn screening tests and their corresponding response rates (2001-2013).

\section{결과}

\section{1. 참여기관 및 회신율}

2001년부터 2013년도까지의 연도별 참여기관 및 회신율은 Fig. 1과 같았다. 2013년도 1차와 2차 신빙도조사에서의 전체 16 기관의 회신율은 $100 \%$ 로 각 기관에서 실제로 시행하고 있 는 검사들에 대해 모두 신빙도조사에 참가 및 회신하였다. 기 본 선별검사 6항목은 총 14 기관, MS/MS를 이용한 광범위 선 별검사항목에 대해서는 해당 검사 시행 중인 총 15 기관이 해 당하였다. MMA검사 4기관, $\mathrm{VMA}$ 검사 7기관, 아미노산 4기 관, 유기산과 초장사슬지방산검사는 3 기관이 각각 참여하였 다.

\section{2. 검사법 및 장비현황}

6 개 질환에 대한 기본 신생아 선별검사에 이용되는 검사방 법은 Fig. 2 와 같았다. 기본 선별검사에는 효소비색법, 효소면 역측정법, 방사선면역측정법과 $\mathrm{MS} / \mathrm{MS}$ 법 등이 이용되어 왔 는데, MSUD, PKU, HCY 선별검사의 경우 면역분석법 대 신 $\mathrm{MS} / \mathrm{MS}$ 법을 사용하는 기관 수가 해마다 증가하고 있으며, 2013년 신빙도조사에서는 총 16 기관 중 14 기관에서 MS/MS 법을 사용하여 결과를 보고하였다. 광범위 선별검사에 이용 된 MS/MS 장비는 제조회사별로 보면 Applied Biosystems

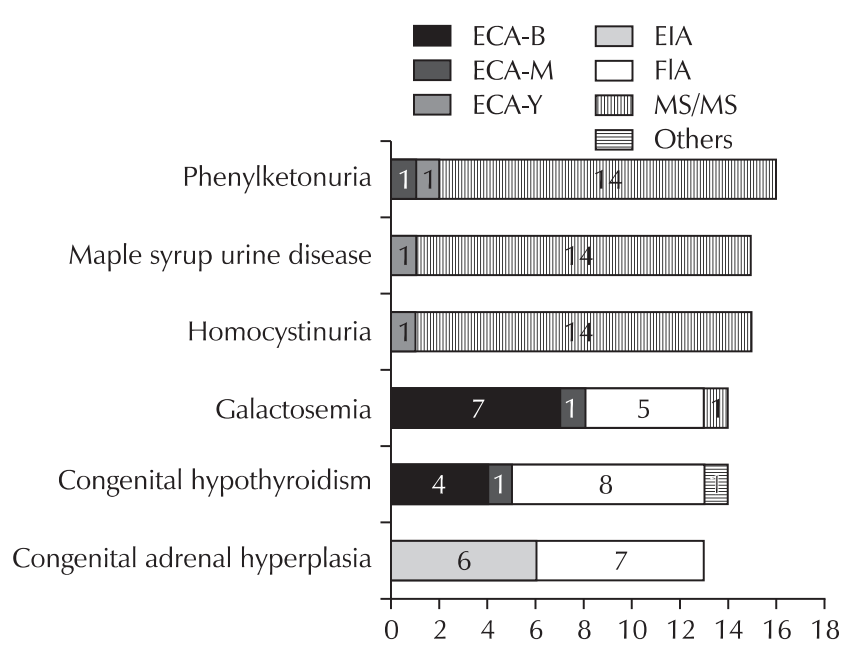

Fig. 2. The analytical methods used for conventional neonatal screening tests in 2013. Abbreviations: ECA-B, enzyme colorimetric assay using Bio-Rad kit; ECA-M: enzyme colorimetric assay using MP Biomedicals kit; ECA-Y, enzyme colorimetric assay using Bayer kit; EIA, enzyme immunoassay using BioRad kit; FIA, fluorometric immunoassay using Perkin-Elmer kit. 
Journal of LABORATORY MEDICINE and QUALITY ASSURANCE

Soo-Youn Lee et al • Quality Assessment of Biochemical Genetics

Table 2. Results of the proficiency testing of conventional neonatal screening tests

\begin{tabular}{|c|c|c|c|c|}
\hline \multirow[b]{2}{*}{ Variable } & \multicolumn{2}{|c|}{ 1st trial } & \multicolumn{2}{|c|}{ 2nd trial } \\
\hline & No. of institutions & $\begin{array}{c}\text { Proportion of correct } \\
\text { answers (\%) }\end{array}$ & No. of institutions & $\begin{array}{c}\text { Proportion of correct } \\
\text { answers (\%) }\end{array}$ \\
\hline Phenylketonuria & 16 & $156 / 159(98)$ & 16 & $159 / 160(99)$ \\
\hline Galactosemia & 14 & $139 / 140(99)$ & 14 & $140 / 140(100)$ \\
\hline Congenital adrenal hyperplasia & 14 & $133 / 135(99)$ & 13 & $129 / 130(99)$ \\
\hline Maple syrup urine disease & 15 & $148 / 150(99)$ & 15 & $148 / 150(99)$ \\
\hline Homocystinuria & 15 & $150 / 150(100)$ & 15 & $150 / 150(100)$ \\
\hline \multicolumn{5}{|l|}{ Congenital hypothyroidism } \\
\hline Thyroid stimulating hormone & 14 & $140 / 140(100)$ & 14 & $140 / 140(100)$ \\
\hline T4, total & 6 & $31 / 36(86)$ & 6 & $34 / 35(97)$ \\
\hline $\mathrm{T} 4$, free & 8 & $78 / 80(98)$ & 8 & $32 / 32(100)$ \\
\hline
\end{tabular}

(Foster City, CA, USA) (8기관)와 Waters (Manchester, $\mathrm{UK})$ (6기관)이었으며, 9기관에서 자체 제조시약을 사용한 반 면, Perkin Elmer사(Shelton, CT, USA)의 상품화된 키트를 사용하는 기관이 5 개 있었다. VMA, MMA, 유기산 및 초장사 슬지방산검사에는 모두 가스크로마토그래피-질량분석법(gas chromatography-mass spectrometry)법이 이용되었으며, 아 미노산 분석에는 액체크로마토그래피-탠덤질량분석법(liquid chromatography-MS/MS)이 이용되었다.

\section{3. 신빙도조사결과}

6종 기본 선별검사와 $\mathrm{MS} / \mathrm{MS}$ 를 이용한 광범위 신생아선 별검사 및 각 항목별 정답률 현황은 Tables 2, 3에 정리하였 다. MS/MS 검사상 포함된 각 항목에 대한 기준치의 분포는 Table 4와 같았다.

각 종목별로 검사방법에 따른 검사결과수치와 기준치, 및 판정결과에 대한상세 자료는 Supplementary Tables 1-21과 Supplementary Figs. 1-6에 정리된 내용을 참조하기 바란다. 신생아 선별검사결과는 Supplementary Tables 1-14, MMA 및 VMA에 대한 결과는 Supplementary Tables 15, 16, 유기 산 분석결과는 Supplementary Tables 17,18 , 아미노산 분석 결과는 Supplementary Tables 19, 20, 초장사슬지방산 분석 결과는 Supplementary Table 21에 제시하였다.

\section{고찰}

생화학유전학분과 신빙도조사사업은 1997년에 처음 시행 되었으며 1998년에 1회, 1999년 2회, 2000년에 2회, 2001년 1 회 시행하였고 2002년도부터는 매년 2회씩 시행하고 있다.
$\mathrm{MS} / \mathrm{MS}$ 를 이용한 광범위 선별검사에 대한 신빙도조사사업은 2007년도부터 시작하였고, 2011년도부터는 아미노산, 유기산, $\mathrm{MMA}, \mathrm{VMA}, \mathrm{VLCFA}$ 분석을 포함하여 종목 확대를 위해 노 력하고 있다.

기본 선별검사 신빙도조사에서는 1 차와 2 차 신빙도조사에 서 회신율은 $100 \%$ 로 타 기관으로 위탁을 보내는 검사항목 은 제외하고 각 기관에서 실제로 시행하고 있는 검사들은 모 두 참가하였다. 2013년도에는 전년도의 결과와 비교하였을 때 비슷한 정도의 항목들에서 결과의 불일치를 보였다(total T4, free T4, 17-hydroxyprogesterone, leucine+isoleucine, galactose, phenylalanine). Leucine+isoleucine, galactose, phenylalanine, free T4의 경우 각 검체에서 1-2 기관에서만 불일치 결과를 보고한 반면, total $\mathrm{T} 4$ 와 17-hydroxyprogesterone의 경우 응답이 일치하지 않는 경 우가 다수 발생하였다. 이러한 경우는 기준치의 차이와 그 에 따른 검사판정기준 및 측정방법에 대한 검토가 필요할 것 으로 판단되었다. 2013년도에는 특히 기준치에 인접한 값 으로 양성이나 음성의 판정결과를 응답하는 항목들(17hydroxyprogesterone, total T4, free T4, phenylalanine, leucine+isoleucine)이 전년도에 비해 많이 있었다. 이러한 기 준치에 인접한 측정값을 나타내는 항목들은 결과판정 일치율 이 $70 \%$ 미만으로 낮아 판정 보류를 한 항목들이 여럿 관찰되 었다. 이를 통해 기관별 측정값, 측정방법, 기준치의 차이와 그 에 따른 판정결과의 차이, 재검률에 대해 각 기관별 면밀한 고 찰이 필요하다.

$\mathrm{MS} / \mathrm{MS}$ 를 이용한 광범위선별검사에서는 1차와 2차에서 각 각 1-2기관이 판정 불일치를 받았으며, 이들 기관에서는 기관 내 기준치 및 검사방법에 대한 검토가 필요할 것으로 판단되 


\section{Journal of LABORATORY MEDICINE and QUALITY ASSURANCE}

Soo-Youn Lee et al $\bullet$ Quality Assessment of Biochemical Genetics

Table 3. Results of the proficiency testing of expanded neonatal screening tests using tandem mass spectrometry

\begin{tabular}{|c|c|c|c|c|}
\hline \multirow[b]{2}{*}{ Variable } & \multicolumn{2}{|c|}{ 1st trial } & \multicolumn{2}{|c|}{ 2nd trial } \\
\hline & No. of institutions & $\begin{array}{c}\text { Proportion of correct } \\
\text { answers (\%) }\end{array}$ & No. of institutions & $\begin{array}{c}\text { Proportion of correct } \\
\text { answers (\%) }\end{array}$ \\
\hline \multicolumn{5}{|l|}{ Amino acids } \\
\hline Arginine & 14 & $84 / 84(100.0)$ & 14 & $84 / 84(100.0)$ \\
\hline Tyrosine & 15 & $90 / 90(100.0)$ & 15 & $90 / 90(100.0)$ \\
\hline Phenylalanine & 15 & $90 / 90(100.0)$ & 15 & $90 / 90(100.0)$ \\
\hline Methionine & 15 & $90 / 90(100.0)$ & 15 & $90 / 90(100.0)$ \\
\hline Citrulline & 15 & $90 / 90(100.0)$ & 15 & $83 / 83(100.0)$ \\
\hline Glycine & 15 & $88 / 89(99)$ & 15 & $90 / 90(100.0)$ \\
\hline Ornithine & 15 & $89 / 90(99)$ & 15 & $90 / 90(100.0)$ \\
\hline Valine & 15 & $90 / 90(100.0)$ & 15 & $90 / 90(100.0)$ \\
\hline Leucine+isoleucine & 13 & $78 / 78(100.0)$ & 13 & $78 / 78(100.0)$ \\
\hline Phenylalanine/tyrosine & 15 & $90 / 90(100.0)$ & 15 & $90 / 90(100.0)$ \\
\hline Methionine/phenylalanine & 14 & $84 / 84(100.0)$ & 14 & $84 / 84(100.0)$ \\
\hline Alanine & 14 & $84 / 84(100.0)$ & 14 & $83 / 83(100.0)$ \\
\hline Histidine & 14 & $78 / 78(100.0)$ & 14 & $84 / 84(100.0)$ \\
\hline Proline & 14 & $84 / 84(100.0)$ & 14 & $84 / 84(100.0)$ \\
\hline Aspartate & 5 & $30 / 30(100.0)$ & 5 & $30 / 30(100.0)$ \\
\hline Glutamate & 7 & $36 / 36(100.0)$ & 6 & $36 / 36(100.0)$ \\
\hline \multicolumn{5}{|l|}{ Acylcarnitines } \\
\hline $\mathrm{C} 0$ & 15 & $84 / 84(100.0)$ & 15 & $84 / 84(100.0)$ \\
\hline $\mathrm{C} 2$ & 15 & $90 / 90(100.0)$ & 15 & $90 / 90(100.0)$ \\
\hline C3 & 15 & $90 / 90(100.0)$ & 15 & $90 / 90(100.0)$ \\
\hline $\mathrm{C} 4$ & 15 & $87 / 89(98)$ & 15 & $90 / 90(100.0)$ \\
\hline $\mathrm{C} 5$ & 15 & $90 / 90(100.0)$ & 15 & $90 / 90(100.0)$ \\
\hline C6 & 15 & $90 / 90(100.0)$ & 15 & $90 / 90(100.0)$ \\
\hline $\mathrm{C} 8$ & 15 & $80 / 80(100.0)$ & 15 & $90 / 90(100.0)$ \\
\hline $\mathrm{C} 10$ & 15 & $90 / 90(100.0)$ & 15 & $90 / 90(100.0)$ \\
\hline $\mathrm{C} 12$ & 14 & $83 / 84$ (99) & 14 & $78 / 78(100.0)$ \\
\hline $\mathrm{C} 14$ & 15 & $89 / 90$ (99) & 15 & $90 / 90(100.0)$ \\
\hline $\mathrm{C} 16$ & 15 & $90 / 90(100.0)$ & 15 & $90 / 90(100.0)$ \\
\hline $\mathrm{C} 18$ & 15 & $90 / 90(100.0)$ & 15 & $90 / 90(100.0)$ \\
\hline C5DC & 15 & $90 / 90(100.0)$ & 15 & $90 / 90(100.0)$ \\
\hline $\mathrm{C} 5-\mathrm{OH}$ & 15 & $89 / 90$ (99) & 15 & 87/88 (99) \\
\hline $\mathrm{C} 3 / \mathrm{C} 2$ & 14 & $78 / 78(100.0)$ & 14 & $78 / 78(100.0)$ \\
\hline
\end{tabular}

었다. 또한 $\mathrm{MS} / \mathrm{MS}$ 검사에서 일부 기관의 경우 $\mathrm{C} 12, \mathrm{C} 3 / \mathrm{C} 2$, C5/C0, C5/C3, C5/C3, C8/C2, C8/C10, alanine, arginine, aspartate, glutamate, histidine, leucine+isoleucine, proline, methionine/phenylalanine 항목에 대해 응답하지 않았
다. 위 항목들에 대하여 현재 보고하지 않는 기관의 경우 자체 적인 검토를 통하여 보고항목으로 추가 고려할 것이 권장된다.

유기산검사는 1 차와 2 차에서 각 3 검체를 발송하였으며, 1 차에서는 모든 기관이 질환명과 기준치 이상의 증가를 보이는 
Table 4. Cut-offs used in expanded neonatal screening tests using tandem mass spectrometry

\begin{tabular}{|c|c|c|c|c|}
\hline Variable & Mean & Median & Minimum & Maximum \\
\hline \multicolumn{5}{|l|}{ Amino acids $(\mu \mathrm{mol} / \mathrm{L})$} \\
\hline Arginine & 54 & 57.3 & 29.1 & 73.7 \\
\hline Tyrosine & 289.8 & 298.7 & 193 & 402 \\
\hline Phenylalanine & 117.7 & 117.2 & 73.4 & 145 \\
\hline Methionine & 61.7 & 60.3 & 37.8 & 86.5 \\
\hline Citrulline & 49 & 50 & 31.9 & 67.9 \\
\hline Glycine & 1032.1 & 1000 & 554.7 & 1794 \\
\hline Ornithine & 301.2 & 287 & 135 & 488 \\
\hline Valine & 274.2 & 280 & 200 & 367.1 \\
\hline Leucine+isoleucine & 304 & 300 & 222 & 400 \\
\hline $\begin{array}{l}\text { Phenylalanine/ } \\
\text { tyrosine }\end{array}$ & 2.4 & 2.5 & 1.3 & 3.8 \\
\hline $\begin{array}{l}\text { Methionine/ } \\
\text { phenylalanine }\end{array}$ & 1 & 1 & 0.5 & 2 \\
\hline Alanine & 661.1 & 680.9 & 475.1 & 850 \\
\hline Histidine & 231.1 & 174 & 1.7 & 667.9 \\
\hline Proline & 416.4 & 359.1 & 5.5 & 1523 \\
\hline Aspartate & 246.7 & 160 & 103.5 & 644.8 \\
\hline Glutamate & 693.5 & 640.1 & 600 & 850 \\
\hline \multicolumn{5}{|c|}{ Acylcarnitines $(\mu \mathrm{mol} / \mathrm{L})$} \\
\hline $\mathrm{CO}$ & 67.97 & 68.4 & 46.92 & 93.79 \\
\hline $\mathrm{C} 2$ & 53.65 & 50 & 39.5 & 80 \\
\hline C3 & 5.28 & 5.2 & 3.29 & 8 \\
\hline $\mathrm{C} 4$ & 0.9 & 0.86 & 0.47 & 1.44 \\
\hline C5 & 0.74 & 0.81 & 0.36 & 1 \\
\hline C6 & 0.3 & 0.2 & 0.1 & 0.7 \\
\hline $\mathrm{C} 8$ & 0.38 & 0.35 & 0.15 & 0.65 \\
\hline $\mathrm{C} 10$ & 0.4 & 0.4 & 0.15 & 0.8 \\
\hline $\mathrm{C} 12$ & 0.48 & 0.47 & 0.19 & 1 \\
\hline C14 & 0.67 & 0.72 & 0.38 & 0.92 \\
\hline C16 & 6.9 & 6.69 & 5.52 & 9.69 \\
\hline $\mathrm{C} 18$ & 1.93 & 1.96 & 0.67 & 3.37 \\
\hline C5DC & 0.26 & 0.25 & 0.14 & 0.46 \\
\hline $\mathrm{C} 5-\mathrm{OH}$ & 0.63 & 0.6 & 0.5 & 0.9 \\
\hline $\mathrm{C} 3 / \mathrm{C} 2$ & 0.27 & 0.3 & 0.1 & 0.39 \\
\hline
\end{tabular}

유기산들을 보고하였으나, 그 상승 정도는 기관별로 큰 차이 를 보였다. 2 차에서는 1 기관이 검출이 기대되는 여러 유기산 중 두 항목(2-keto-3-methylvaleric acid와 2-ketoisocaproic acid)을 보고하지 않아 자체적인 검토를 통하여 보고항목으로 추가할 것을 권장하였다. 2차에서도 1차와 2012년 결과와 동 일하게 측정값의 범위가 기관별로 차이가 큰 것으로 나타났으 며, orotic acid에 대해서는 응답한 모든 기관에서 유사한 측정 값을 나타내었다.

아미노산검사는 1 차 및 2 차 각각 2 검체를 발송하였으며, 4 기관이 참여하여 각 기관이 제출한 측정값을 제시하는 것으로 평가를 대신하였다. 모든 기관이 질환명과 기준치 이상의 증가 를 보이는 성분들을 보고하였으나, 그 상승 정도는 기관별로 차이를 보였다. 2 차에서는 비록 임상정보가 없는 검체이나 결 과해석에 증감 양상과 각 성분들 간의 상대적 비율 등을 고려 하여 판정해야 하며, 비특이적 양상을 보이는 경우에는 2 차성 으로 증가할 수 있는 다른 질환상태나 검체 조건을 고려하는 등 해석에 주의가 필요할 것으로 판단되었다.

초장사슬지방산검사는 1 차 및 2 차 각각 2 검체를 발송하였 으며, 3 기관이 참여하였고, 대부분 일치하는 결과를 보였으나 2차에서 기준치에 인접한 측정값을 나타내는 $\mathrm{C} 26: 0 / \mathrm{C} 22: 0$ 항목에 대해서는 결과판정이 일치하지 않았다. 요중 $\mathrm{VMA}$ 와 $\mathrm{MMA}$ 정량검사는 기관 간 결과값이나 판정이 비교적 잘 일치 하였다.

선천성대사질환에 대한 신생아선별검사는 검사수치뿐 아니 라 결과에 대한 정상 및 비정상에 대한 적절한 판독이 매우 중 요하다. 그러나 각 기관에서 검사에 사용하는 시약과 검사방법 이 다양하고 정상 및 비정상을 평가할 기준치가 서로 다른 경 우가 많았다. 또한 생화학유전학분과 신빙도조사에서 겪는 애 로사항으로 동일검사법 이용기관의 수가 적은 경우 비교 불가 한 점, 다양한 질환 양성 검체를 대량 확보하기 어려운 점, 단 일 성분만이 아닌 다수의 증감 양상이 조합된 검체를 준비해야 하는 점 등이 있었다. 각 기관에서는 신빙도조사결과를 자체적 으로도 면밀히 검토 분석하여 분석법의 신뢰성을 확인하고 내 부정도관리를 강화함과 동시에 주기적으로 기준치를 검증하 고 결과보고종목 및 결과해석의 차이도 점검해보는 것이 매우 중요할 것으로 생각된다. 앞으로도 종목 확대, 적절한 정도관 리물질의 확보, 워크샵 개최를 통한 관련 인력교육을 포함하여 지속적으로 신빙도조사 프로그램을 개선 발전시킬 수 있는 방 향을 모색한다면 생화학유전검사의 질 향상에 기여할 수 있을 것으로 전망한다.

\section{감사의 글}

정도관리물질 제조관리와 결과자료분석 등 본 신빙도조사를 위해 수고해주신 삼성서울병원 진단검사의학과 특수화학검사 
실 직원 여러분들과 전공의 선생님들께 감사드린다.

\section{생화학유전분과위원회 분과위원(2013)}

이수연(위원장, 성균관대학교 의과대학), 박병택(간사, 삼성 서울병원), 권계철(충남대학교 의과대학), 김정호(연세대학교 의과대학), 김종원(성균관대학교 의과대학), 박형두(성균관대 학교 의과대학), 송정한(서울대학교 의과대학), 이은희(녹십 자의료재단), 전사일(울산대학교 의과대학), 최태윤(순천향대 학교 의과대학)

\section{SUPPLEMENTARY MATERIALS}

Supplementary materials can be found via http:// pdf.medrang.co.kr/LMQA/2014/036/LMQA036-02-02_ Supple1.pdf

\section{REFERENCES}

1. Song J, Kwon KC, Kim JH, Kim JW, Min WK, Lee SY, et al. Annual report on external quality assessment in metabolic disorders in Korea (2007). J Lab Med Qual Assur 2008;30:151-66.

2. Lee SY, Kwon KC, Kim JH, Kim JW, Park BT, Park HD, et al. Annual report on external quality assessment in biochemical genetics in Korea (2012). J Lab Med Qual Assur 2013;35:S29-63.

3. Lee SY, Kwon KC, Kim JH, Kim JW, Park BT, Park HD, et al. Annual report on external quality assessment in biochemical genetics in Korea (2011). J Lab Med Qual Assur 2012;34:S25-49.
생화학유전분과 신빙도조사 결과보고(2013)

이수연 • 대한임상검사정도관리협회 생화학유전학분과위원회

성균관대학교 의과대학 삼성의료원 진단검사의학교실

2013년도 생화학유전학분과 신빙도조사사업은 총 2회 시행되었다. 페닐케톤뇨증, 갈락토오스혈증, 선천성 부신형성과다증, 단풍당뇨증, 호모시스틴뇨증, 선천성 갑상선기능저하증을 포함하는 선천성 대사질환 기본 선별검사와 탠덤질량분석기를 이용한 광범위 선별검사를 위한 총 32 개의 건조혈액여 과지 검체를 16 기관에 발송하였다. 회신율은 $100 \%$ 로, 타 기관으로 위탁을 보내는 검사항목은 제외 하고 각 기관에서 실제로 시행하고 있는 검사들은 모두 참가하였다. 특히 기준치에 인접한 값을 보이 는 검체들이 포함되어 결과판정 일치율이 $70 \%$ 미만으로 낮아 판정 보류를 한 항목들이 관찰되었다. 타 기관과 차이 나는 측정값 또는 판정을 보이는 경우에는 기관별 측정값, 측정방법, 기준치의 차이와 그에 따른 판정결과의 차이나 결과해석방법 등에 대해 각 기관별로 면밀한 자체 검토가 필요할 것으 로 판단되었다. 이외 메틸말론산과 바닐만델산, 유기산, 아미노산 및 초장사슬지방산항목에 대한 신 빙도조사도 시행되었으며 대부분 만족스러운 결과를 보였다. 외부정도관리 프로그램과 지속적인 교 육을 통하여 생화학유전검사의 질을 향상시킬 수 있을 것으로 기대된다.

(J Lab Med Qual Assur 2014;36:64-70)

교신저자: 이수연

우) 135-710 서울시 강남구 일원로 81, 성균관대학교 의과대학 삼성서울병원 진단검사의학교실

Tel: 02)3410-1834, Fax: 02)3410-2719, Email: suddenbz@skku.edu

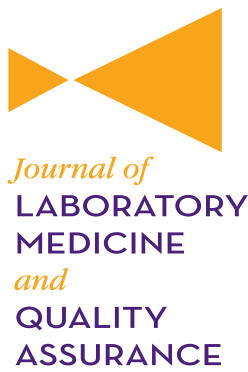

ASSURANCE 